\title{
Audiobook: Alternative Communication Media In Disseminating Disaster Mitigation Information For Children With Visual Impairments
}

\author{
Susie Perbawasari ${ }^{1}$, Heru Ryanto Budiana ${ }^{2}$, Hanny Hafiar ${ }^{3}$, Diah Fatma Sjoraida ${ }^{4}$, Indah \\ Suryawati ${ }^{5}$ \\ \{email: susie.perbawasari@unpad.ac.id; hanny.hafiar@unpad.ac.id\} \\ 1,2,3,4 Universitas Padjadjaran, Bandung, Indonesia \\ ${ }^{5}$ Universitas Budi Luhur, Jakarta, Indonesia
}

\begin{abstract}
Information related to earthquake disaster mitigation currently spread in various media, mostly in the form of text. This makes it difficult for disabilities children with visual impairments to access this information. In fact, people with disabilities and children are the most vulnerable parties to be affected by the disaster. Therefore, this study aims to find alternative solutions to increase knowledge about protection and survival techniques for students with visual impairments. The method used is the descriptive case study through mapping problems and finding alternative solutions obtained based on the results of interviews, observation and focus group discussions. The results obtained were that there were several problems that were successfully mapped, including: being unable to see the text, not proficient in reading braille, limited understanding in reading sentences, unable to see illustrations and demonstrations, lack of understanding of the concept of natural disasters, no experience with earthquakes, do not have visual knowledge about the impact of the earthquake, do not have a natural awareness of disasters. Alternative steps are taken to disseminate disaster mitigation information to students with visual impairments through the making of audiobooks. The activity was carried out in several stages. namely: Problem mapping, Preparation of plans for making media that are tailored to the needs, Preparation of material on disaster mitigation, media creation, testing, repair, re-testing, implementation of disaster mitigation simulations.
\end{abstract}

Keywords: Audiobook, Media, Disaster Mitigation, Information, Children With Visual Impairments

\section{Introduction}

An earthquake is one of the natural disasters that often occurs in Indonesia. This happens because $80 \%$ of Indonesia's territory is located in high-risk seismic areas in the world. In West Java Province, several cities have experienced earthquake natural disasters, which can be felt up to the West Java capital city, Bandung, those several cities namely: Sukabumi (January 2, 2019), Pangandaran (May 18, 2019), Garut (April 11, 2019), and Tasikmalaya (7 January 2019). Even so, according to the results of mapping earthquake patterns in Indonesia with the fractal method, Java Island has the lowest fractal number for areas with earthquake disaster vulnerability [1]. 
Despite having the lowest fractal numbers, earthquakes are natural disasters that are still difficult and complex to predict. Therefore, people must always be vigilant and know how to save themselves when an earthquake occurs. There are a number of information media that present procedures for saving themselves during natural disasters, but most of the media information is in the form of text. This makes it difficult for visually impaired people to be able to access and understand the information. Therefore, for persons with disabilities, especially visual impairments, other forms of media are needed regarding procedures for saving themselves during natural disasters.

There are several problems faced by people with disabilities when dealing with disasters, which are related to the stages of disaster management. These problems when referring to the 2012 Disabled Rights Consortium, among others: have not been maximally sensitive disaster preparedness programs for people with disabilities; participation of people with disabilities is still minimal in disaster risk reduction (DRR) education; accessibility of people with disabilities to DRR teaching/learning material; people with disabilities cannot fully act quickly in saving themselves; lack of specific data on the identity and condition of people with disabilities;Lack of facilities and services that are accessible in refugee camps [2]

In Bandung city, there are 45 Special Schools (SLB), one of them is SLB Negeri A, Bandung, located on Pajajaran street. In order to minimize casualties, it is necessary to disseminate information about natural disasters for persons with disabilities, especially people with visual impairment, which contains information on governance, protection techniques and self-rescue from earthquake disasters. One of the media that can be used to provide information to people with visual impairment is in the form of audiobooks. The audiobook is a recording of the contents of a book or writing, whether in the form of text, images, photos, or other illustrations which are made in audio form so that the audience can receive the information in the form of sound. The substance of the audiobook is exactly the same as in the textbook but the word spoken is not always exactly the same as the version of the book. the benefits of audio media are being able to understand the contents of a book without having to read, even while doing daily activities. [3].

Audiobooks are one of the alternative media that can be used to provide understanding to students who have visual impairments, especially for students who are not fluent in reading and understanding. The audiobook can contain information about earthquakes and procedures for saving themselves during an earthquake. By using language styles that are appropriate and able to be understood by children at the elementary school level.

Thus, it is expected that the dissemination of information about earthquakes can be conveyed so that it can minimize the occurrence of panic at the time of the disaster. In addition, the role of parents and teachers is very important in disseminating information. Therefore, infographics regarding things that must be done before, during, and after the occurrence of earthquake natural disasters are also needed by parents and elementary school teachers. Based on this, the research aims to describe needs, problem mapping, and alternative solutions in providing media information about disaster mitigation for students with visual impairment

\section{Method}

Based on the conditions found in the field, this study uses a descriptive case study method with data collection techniques through interviews, observation and focus group discussions. 
Interviews were conducted with a number of parties, including teachers and students, to map field conditions related to information needs regarding disaster mitigation, especially earthquake disasters. Furthermore, observations were made regarding the stages of making an audiobook and its uses.

\section{Results and discussion}

In accordance with the information obtained from one of the teachers who taught at SLBN $\mathrm{A}$ in the City of Bandung, until now there has been no counseling or simulation regarding the escape from earthquake disasters given to students with visual impairments at the SLBN A. In fact, this self-rescue needs to be mastered by every student, especially students with special needs, considering the earthquake disaster can occur anytime and anywhere. To respond to this, the research team sought to conduct research while providing information about earthquake disaster mitigation by making audiobooks. Audiobooks can be an alternative for students with visual impairments as a substitute for reading books. As for teachers and parents of students, as a companion, infographics are provided to facilitate teachers and parents of students to understand and remember information about the earthquake mitigation.

Knowledge of the techniques of protection and escape from earthquakes for students with visual impairments is still lacking. One reason is the lack of education for parents of children who still do not know about the techniques of protection and self-rescue from the earthquake. On the other hand, parents and the community, not many people understand the surrounding problems, especially about the geographical location of Bandung which is prone to natural disasters such as earthquakes. This limited knowledge is indicated by the high incidence of earthquake victims in the community, especially among people with visual impairment.

This activity was carried out as an effort to find alternative solutions to increase knowledge about protection and self-rescue techniques for students with visual impairments. The activity was carried out in several stages. These stages are Problem mapping, Preparation of plans for making media that are tailored to needs, Preparation of material on disaster mitigation, media creation, testing, repair, re-testing, implementation of disaster mitigation simulations. The results of mapping and finding alternative solutions are presented in Table 1.

Table 1. Mapping problems and finding alternative solutions

\begin{tabular}{ll}
\hline Mapping Problems & Alternative solutions \\
\hline $\begin{array}{l}\text { Cannot see text } \\
\text { Not yet adept at reading braille } \\
\text { Limited understanding in reading sentences }\end{array}$ & $\begin{array}{l}\text { Changing the format of presenting information } \\
\text { from text to audio narration }\end{array}$ \\
\hline $\begin{array}{l}\text { Can't see the illustration } \\
\text { Can't see the demonstration }\end{array}$ & $\begin{array}{l}\text { Changing the visual presentation format of the } \\
\text { image into an auditive sound effect }\end{array}$ \\
\hline $\begin{array}{l}\text { Lack of understanding of the concept of natural } \\
\text { disasters }\end{array}$ & $\begin{array}{l}\text { Providing information about causes, symptoms, } \\
\text { events, consequences, and impacts of earthquake } \\
\text { disasters on humans and the environment }\end{array}$ \\
$\begin{array}{l}\text { Have no experience regarding earthquakes } \\
\text { Don't have visual knowledge about the impact of }\end{array}$ & $\begin{array}{l}\text { Not yet obtained information about earthquake } \\
\text { disaster mitigation }\end{array}$ \\
Not yet have natural awareness of disasters & $\begin{array}{l}\text { Providing information on earthquake disaster } \\
\text { mitigation followed by simulations. }\end{array}$ \\
\hline
\end{tabular}


Some studies show that people with disabilities are more likely to be affected in a civil emergency and are less likely to be prepared. Management of emergency preparedness needs to involve disabled people in the community and have special policies to help disabled people before and in the event of a disaster [4]. In previous studies, it was revealed that people with disabilities or disabilities are those affected more severely because the evacuation, emergency response, and rehabilitation processes are often not according to their needs [5].

So is the case with children, because children are very fragile, emotionally and physically sensitive, and more vulnerable than adults in the event of an emergency. They cannot tell their worries and fears as adults can. Therefore, they need to be protected and guarded their rights; this is done through roles that can be performed by parents and government regulations. A nation's top priority for having a healthy generation can be achieved by taking the necessary precautions in the face of disasters, including earthquakes [6], especially to protect the physical and psychological conditions of children as future generations. Based on the statement, it can be said that persons with disabilities and children are the two most vulnerable parties affected by disasters compared to other parties. So that the impact of the disaster will be doubled if a child with a disability is faced with a catastrophic event.

Ironically, a study says that children with disabilities often escape from disaster risk reduction activities, and as a result, children with disabilities can experience physical, and psychological vulnerability [7], which is more severe. According to the American Foundation for the people with visual impairment. People with visual impairment are vulnerable groups that can be greatly affected by the effects of disasters [8]. So, among groups of children with disabilities, children with visual impairments have a large risk of disaster relief.

Therefore, inclusive education on disaster risk management is important to be studied together so that it can provide equal opportunities for people with visual impairment to access information and receive education at all stages of disaster response, rehabilitation and recovery. The most effective way to improve disaster risk management education for people with visual impairment is to involve them in the learning process as active students, not as passive recipients [9].

This is important considering that Indonesia is a country that has the infrastructure that has not been fully designed to anticipate earthquakes. This is exacerbated by the condition of traditional infrastructure, the structure of daily life, and emergency disaster procedures, more designed for the public, not for people with disabilities [10]. This condition does not only occur in developing countries such as Indonesia but in a developed country there is a similar complaint which states that there is a difficulty faced by a father to find individualized safety plan facilities for his vision impaired son, at school. Even templates for individual safety plans are not yet available from the Ministry of Education, nor from the blindness agencies [11]. Therefore, the recommendation for future research is the need for studies to bridge the knowledge gap and help establish disaster policies in suitable and inclusive schools for children with disabilities [12].

Based on the conclusions of a study that took place in Aceh after the earthquake and tsunami, it was said that: the preparedness of people with visual impairment for earthquake and tsunami disasters was not optimal. The forms of preparedness needed by people with visual impairment are the application of Standard Operating Procedures and capacity building education; sources of knowledge and attitudes towards disasters were obtained from the family, the institution manager, and the community concerned with the disability. [13]. The forms of communication that can be done in providing disaster information are through discussion and socialization. Therefore, schools that have students with disabilities need to 
ensure that disaster mitigation communication has been carried out, in schools and outside schools, for example by communicating which involves parents of students [14]

Disaster mitigation communication activities for children with visual impairments disabilities with special media and methods. Efforts that need to be done to improve the abilities of people with visual impairments, can be done through the use of fun learning media, for example, accompanied by a background of cheerful music sounds [15]. Therefore, the media that is in accordance with their conditions are auditive media, such as audiobooks. The audiobook is a digital recording of books that have been recorded in advance to make it easier for people with visual impairment to "read" a book by listening to the audio file [16]. This media can be another solution for children with visual impairment who want to read books if they are not yet good at reading using braille books. In fact, the history of the birth of audiobooks was intended to help people with disabilities, especially those who were visually impaired, but could also be used by groups of people who could not read (illiterate) [17]. In addition to making audiobooks as a communication medium in disseminating disaster mitigation information for children with visual impairment, it is also necessary to fulfill the needs of children with visually impaired during disasters, namely: landmarks, hand-rails, personal support, good lighting and queues separate. In addition, it is necessary to consider the disaster warning system in the form of a sound/alarm based signal system, and oral announcements, as well as posters written in large letters and striking colors [5], which can provide guidance for children with visual impairments in the low vision category.

In addition to providing disaster mitigation information through various alternative communication media in accordance with conditions experienced by disabilities, people with disabilities also need post-disaster handling and rehabilitation [18] because new problems tend to add to the problems faced by people with disabilities, especially people with disabilities in the children category.

\section{Conclusion}

The level of knowledge possessed by students with visual impairment related to protection techniques and self-rescue from earthquakes tends to be lacking. This is due to the absence of counseling or socialization activities on the management of self-rescue from earthquakes for students with visual impairment. There are several problems that can be mapped that relate to disaster mitigation for students with visual impairment, namely unable to see texts, not yet proficient in reading braille, limited understanding in reading sentences, unable to see illustrations and demonstrations, lack of understanding of the concept of natural disasters, lack of experience regarding the earthquake, not yet having visual knowledge about the impact of the earthquake, it does not yet have a natural awareness of disasters.

Alternative solutions were obtained to increase knowledge about protection and self-rescue techniques for students with visual impairment, namely through the creation of communication media audiobooks containing information on disaster mitigation that was packaged according to the conditions of students with visual impairment who were still in the children category. To produce effective audiobook media, the production process is carried out in several stages. These stages are problem mapping, preparation of plans for making media that are tailored to the needs, preparation of material on disaster mitigation, media creation, testing, repair, re-testing, implementation of disaster mitigation simulations. 


\section{References}

[1] D. R. Galih and L. Hadayani, "Pemetaan Pola Terjadinya Gempa Bumi Di Indonesia Dengan Metode Fraktal," J. Ris. Geol. dan Pertamb., vol. 17, no. 2, p. 51, 2015.

[2] A. D. Santoso, I. Noor, and M. C. Ulum, "Disabilitas dan Bencana (Studi tentang Agenda Setting Kebijakan Pengurangan Risiko Bencana Inklusif Bagi Penyandang Disabilitas di Kabupaten Klaten , Jawa Tengah , Indonesia)," J. Adm. Publik (JAP, vol. 3, no. 12, pp. 2033 2039, 2015.

[3] F. Camalia, H. Susanto, and Susilo, "Pengembangan Audiobook Dilengkapi Alat Peraga Materi Getaran Dan Gelombang Untuk Tunanetra Kelas," Unnes Phys. Educ. J., vol. 5, no. 2, pp. 6779, 2016.

[4] S. Phibbs, G. Good, C. Severinsen, E. Woodbury, and K. Williamson, "Emergency preparedness and perceptions of vulnerability among disabled people following the Christchurch earthquakes: Applying lessons learnt to the Hyogo Framework for Action," Australas. J. Disaster Trauma Stud., vol. 19, no. Special issue, pp. 37-46, 2015.

[5] R. Probosiwi, "Keterlibatan Penyandang Disabilitas Dalam Penanggulangan Bencana," J. Penanggulangan Bencana, vol. 4, no. 2, pp. 13-22, 2013.

[6] Ş. Ersoy and A. Koçak, "Disasters and earthquake preparedness of children and schools in Istanbul, Turkey," Geomatics, Nat. Hazards Risk, vol. 7, no. 4, pp. 1307-1336, 2015.

[7] S. Ronoh, J. C. Gaillard, and J. Marlowe, "Children with Disabilities and Disaster Risk Reduction : A Review,” Int. J. Disaster Risk Sci., vol. 6, pp. 38-48, 2015.

[8] S. Madanian and D. Airehrour, "Smart Cap for Visually Impaired in Disaster Situations."

[9] K. Kharade, "Empowering Students with Visual Impairment to Prepare for Disasters via Differentiated Instruction Technique : A Case Study in India," Int. J. Spec. Educ., vol. 32, no. 3, pp. 567-585, 2017.

[10] I. Kelman and L. Stough, "(Dis)ability and (Dis)aster," in Disability and disaster : Explorations and exchanges, no. 1, 2015.

[11] G. A. Good, "Emergency plans in schools : Individualised disaster planning for students with impaired vision," J. South Pacific Educ. Vis. Impair., vol. 8, no. 1, pp. 17-29, 2015.

[12] H. J. Boon et al., "School Disaster Planning For Children With Disabilities A Critical Review Of The Literature," Int. J. Spec. Educ., vol. 26, no. 3, pp. 223-237, 2011.

[13] D. Mubarrak, Nazli, and T. Husin, "Kesiapsiagaan Tunanetra Terhadap Bencana Gempabumi Dan Tsunami (Penelitian di UPTD Rumoh Seujahtera Beujroh Meukarya Aceh Besar)," J. Ilmu Kebencanaan, vol. 4, no. 2, pp. 65-71, 2017.

[14] F. N. Indriasari, "Pengaruh Pemberian Metode Simulasi Siaga Bencana Gempa Bumi Terhadap Kesiapsiagaan Anak Di Yogyakarta,” J. Keperawatan Soedirman, vol. 11, no. 3, pp. 1-7, 2016.

[15] R. F. Duwingik, D. N. P. Kasim, D. Ayu, M. A. Dano, and I. N. Manyoe, "Survey And Efforts To Improve Mitigation Ability For Disability Students In Gorontalo City.," Duwingik, dkk., 2019 J. Sains Inf. Geogr. [JSIG], vol. 2, no. 1, pp. 40-43, 2019.

[16] M. R. Handayani, "Audiobook sebagai alat bantu memperlancar komunikasi dalam penyebaran dakwah islam penyandang tunanetra," Islam. Commun. J., vol. 01, no. 01, pp. 19-29, 2016.

[17] O. M. Anwas, "Audiobook: Media Pembelajaran Masyarakat Modern," J. Teknodik, vol. 18, no. 1, pp. 54-62, 2014.

[18] F. Itriyati and D. D. Asriani, "Politik Pengakuan Perempuan dengan Disabilitas Pasca Bencana Gempa di Yogyakarta," J. Pemikir. Sosiol., vol. 1, no. 2, pp. 52-68, 2012. 